EISSN: $2706-7947$ ISSN: 2077- 4613

DOI: 10.36632/mejas/2021.11.2.46

Journal homepage: www.curresweb.com

Pages: 589-594

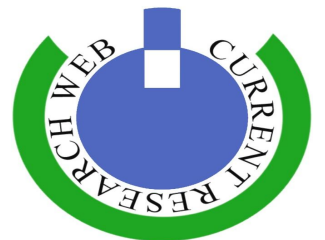

\title{
Essential oil content and composition of endemic Origanum syriacum ssp. sinaicum and it's antimicrobial activity
}

\author{
M. Abd El-Motaleb ${ }^{1}$, Asmaa R. Abd El-Hameid ${ }^{1}$, Wafaa A. Helmy ${ }^{2}$, E.A. Ewais ${ }^{3}$ and M. \\ S. Abdel-Hady ${ }^{1}$
}

${ }^{1}$ Botany Department, National Research Centre, 33 El Buhouth St., 12622 Dokki, Giza, Egypt.

${ }^{2}$ Chemistry of Natural and Microbial Products Department, National Research Centre, 33 El Buhouth St., 12622 Dokki, Giza, Egypt.

${ }^{3}$ Botany and Microbiology Department, Faculty of Science, Al-Azhar University, Madinet Nasr, 11884, Cairo, Egypt.

Received: 15 May $2021 \quad$ Accepted: 20 June $2021 \quad$ Published: 30 June 2021

\begin{abstract}
Numerous endemic plants grow naturally in Egypt especially in South Sinai Peninsula at Saint Katherine protectorate, one of those important plants is Origanum syriacum ssp. Sinaicum. Leaves of Origanum plants have an important role in both modern and folk medicine due to their secondary metabolites (Essential oil). The essential oil yield quantity of $O$. syriacum hydro-distilled through Clevenger apparatus was $6.5 \%$. The chemical compositions of the essential oil obtained by hydrodistillation were analyzed by gas chromatography-mass spectrometry (GC-MS). Major component of GC-MS analysis essential oil detected as oxygenated monoterpenes was carvacrol $(95.37 \%)$. The essential oil of $O$. syriacum leaves was found to possess antibacterial activity against Gram-positive as well as Gram-negative bacteria and antifungal activity against Candida albicans.
\end{abstract}

Keywords: Origanum syriacum, Essential oil, GC-MS, Hydrolysis, Carvacrol, Antimicrobial.

\section{Introduction}

Origanum Syriacum subsp. sinaicum plant is a very rare plant grown in rocky stony lands in Sinai and commonly used in folk medicine by Bedouins in this region. Leaves of O. syriacum traditionally used as steam inhalation, spice flavor, fragrance, vaporization, and massage. It is used as a tea and in baking or cooking foods (Alma et al., 2003).

Moreover, nine hundred (900) species of genus Origanum widespread throughout the global, about 38 species of Origanum were found native to the Mediterranean countries (Kordali et al., 2008).

Origanum syriacum ssp. sinaicum is a Perennial herb considers as low under-shrub reach $90 \mathrm{~cm}$. in tall, has numerous branched erect stems with broadly ovate leaves, and encompasses most of the endemic species in Egypt which grow only in South Sinai at Saint Katherine Peninsula (Boulos, 2002).

The smell related with $O$. syriacum plants emerges from the essential oil found in peltate glandular trichomes on the airborne parts of the plant. These glandular trichomes comprise of profoundly specialized secretory cells in which the components of the essential oil are synthesized and accumulated in a subcuticular storage cavity (Turner et al., 1999).

The essential oils of $O$. syriacum were found to contain mainly thymol and/or carvacrol, monoterpene glycosides, phenols such as gallic acid, rosmarinic acid, caffeic acid, apigenin, naringenin, and luteolin-7-O-glucoside. These compounds are responsible for the aroma and flavour of these plants, whereas carvacrol is a highly useful phenol with a wide range of biological activity, and anti-microbial (Bisht et al., 2010), Essential oils (EOs) can be extracted and utilised in modern pharmaceuticals, food and cosmetics industries as a flavoring, antifungal, antibacterial, antiseptic and antioxidant agents (Sharifi-Rad et al., 2017). 
According to a prediction by (Poulose and Croteau, 1978), the aromatic chemical p-cymene serves as an intermediary in the production of thymol, which starts with $\gamma$-terpinene. Despite extensive efforts to breed oregano and thyme varieties with higher proportions of thymol and carvacrol for pharmaceutical use, as well as interest in these terpenes as plant defences.

Unfortunately, oregano has been subjected to excessive use for many years, while the crop plant has been destroyed by harvesting. In addition, urbanization pressure and uncontrolled forest fires are posing major threats to the species' survival in Sinai. The collection of plants from the wild has put the species in danger. In Egypt, there's an expanding concern with the natural life components and their preservation, in spite of the fact that such a preservation administration on scientific bases is still required. Numerous studies meant by Saint Kathrine protectorate have been done but almost of these studies focused on the ecology and the flora counting of flora including threatened species (Moustafa, 2001).

The present work aimed to assessment of the chemical composition and percentage of wild Origanum syriacum ssp. sinaicum essential oil. As well as, determination the antimicrobial potential of wild $O$. syriacum ssp. sinaicum essential oil.

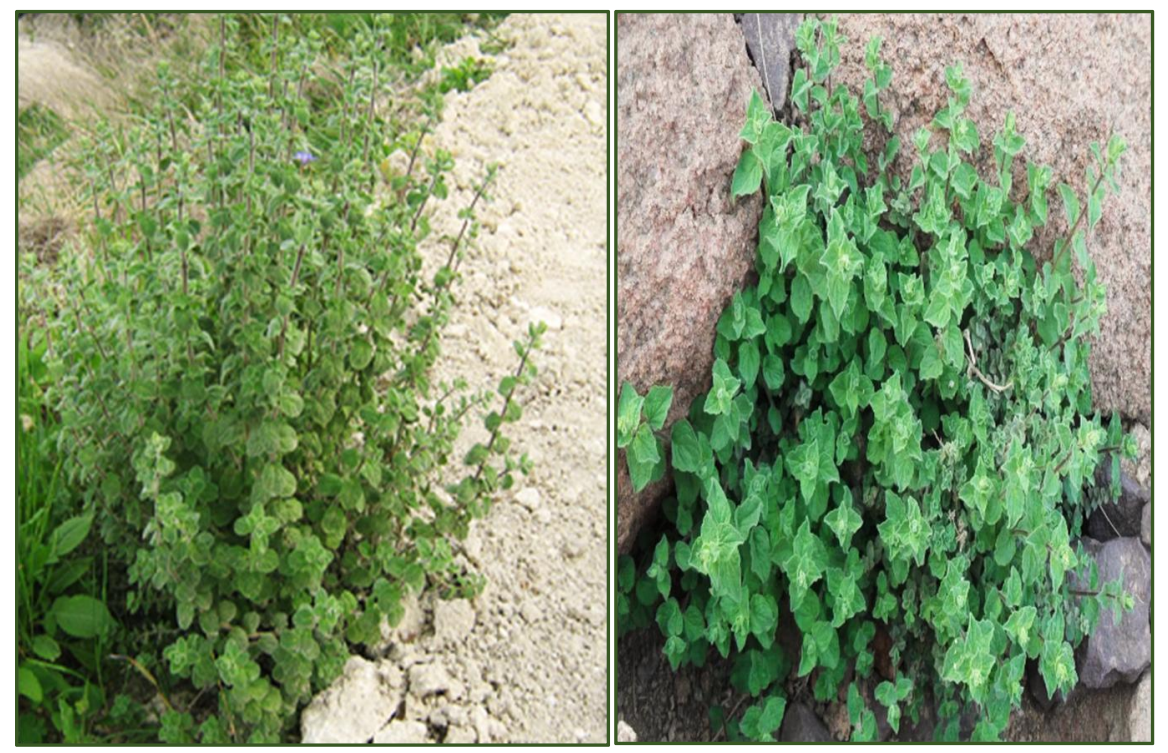

Fig. 1: Wild Origanum syriacum ssp. sinaicum in natural habitat.

\section{Materials and Methods}

The present investigation was carried out at Botany Department, Agricultural and Biological Researches Division, National Research Centre, Cairo, Egypt.

\subsection{Collection of plant materials:}

Seeds and aerial parts of Origanum syriacum ssp. sinaicum were obtained from Saint Katherine protectorate, South Sinai, Egypt, by Ahmed Abdallah Mohamed (Abdallah A.) Environmental researcher, Natural Conservation Sector (NCS), Egyptian Environmental Affairs Agency (EEAA).

\subsection{Essential oil extraction:}

Air dried leaves of wild plants were extracted by physical hydrolysis via Cleavinger apparatus. Essential oil of $O$. syriacum leaves was extracted by hydro-distillation Clevenger apparatus method at the boiling range of water for 3 hours and atmospheric pressure Baser and Buchbauer (2009).

\subsection{Gas chromatography-mass spectrometry analysis (GC-MS):}

The GC-MS system (Agilent Technologies) was equipped with gas chromatograph (7890B) and mass spectrometer detector (5977A) at Central Laboratories Network, National Research Centre, Cairo, Egypt. 
Samples were diluted with hexane (1:19, v/v). The GC was equipped with HP-5MS column (30 $\mathrm{m} \times 0.25 \mathrm{~mm}$ internal diameter and $0.25 \mu \mathrm{m}$ film thickness). Analyses were carried out using hydrogen as the carrier gas at a flow rate of $1.0 \mathrm{ml} / \mathrm{min}$ at a split less of, injection volume of $1 \mu 1$ and the following temperature program: $40{ }^{\circ} \mathrm{C}$ for $1 \mathrm{~min}$; rising at $4{ }^{\circ} \mathrm{C} / \mathrm{min}$ to $150{ }^{\circ} \mathrm{C}$ and held for $6 \mathrm{~min}$; rising at $4{ }^{\circ} \mathrm{C} / \mathrm{min}$ to $210{ }^{\circ} \mathrm{C}$ and held for $1 \mathrm{~min}$. The injector and detector were held at $280{ }^{\circ} \mathrm{C}$ and $220^{\circ} \mathrm{C}$, respectively. Mass spectra were obtained by electron ionization (EI) at $70 \mathrm{eV}$; using a spectral range of $\mathrm{m} / \mathrm{z} 50-550$ and solvent delay $5 \mathrm{~min}$. Identification of different constituents was determined by comparing the spectrum fragmentation pattern with those stored in Wiley and NIST Mass Spectral Library data.

\subsection{Antibacterial assay:}

The antimicrobial assay was performed by agar well diffusion method (Valgas et al., 2007). 0.6 $\mathrm{ml}$ of standardized bacterial stock suspensions (108-109) colony- forming units per $\mathrm{ml}$ was thoroughly mixed with $60 \mathrm{ml}$ of sterile nutrient agar. $20 \mathrm{ml}$ of the inoculated nutrient agar were distributed into sterile Petri dishes. Spreading a volume of the microbial inoculum (Bacillus subtilis, Bacillus cereus. and Staphylococcus aureus as a gram-positive while Escherichia coli as a Gram-negative) and Candida albicans over the entire agar surface. Then, a hole with a diameter of 6 to $8 \mathrm{~mm}$ is punched aseptically with a sterile corkborer or a tip. A volume of $100 \mu 1$ of essential oil of at concentration $1000 \mathrm{mg} / \mathrm{ml}$ was introduced into the well. Then, agar plates were incubated under $37^{\circ} \mathrm{C}$ for $24 \mathrm{~h}$. The experiment was carried out three times and the mean values were presented. The antimicrobial activity was evaluated by measuring the diameter of inhibition zone (DIZ) $\mathrm{mm}$.

\subsection{Data analysis:}

The experiments were carried out in a completely random way. Anova, a statistical analysis software, was used to do data variance analysis. Duncan's multiple range tests were used to show the differences between means for all treatments were significant at the $5 \%$ level. At $\mathrm{P} \leq 0.05$.

\section{Results and Discussion}

\subsection{Estimation of Essential oil of Origanum syriacum var sinaicum.}

\subsubsection{Essential oil extraction:}

Essential oil extracted from air dried leaves of Origanum plants after 3 hours of boiling $6.5 \%$ of yellow oil condensed as a layer on the water surface from Origanum leaves, which dried over anhydrous sodium sulfate and collected in dark sterilized vials and stored in refrigerator for further studies.

The oil yield quantity $(6.5 \%)$ that was obtained from the sample was relative to that published by Gendy et al. (2015) who extracted 5.5\% from Origanum syriacum and Economou et al. (2011) who found $7.77 \%$ essential oil from $O$. vulgare L. ssp. Gracile. The higher quantity of essential oil in wild plants is due to a lot of reasons, including biotic and abiotic stresses that affected the plants in their natural habitats, causing plants to produce large amounts of secondary metabolites.

\subsubsection{Gas chromatography-mass spectrometry analysis (GC-MS):}

Data presented in Table (1) and in figure (2) illustrated that essential oil component that present in wild plants.

Essential oil obtained from wild plants composed from 13 compounds was listed in Table (1). The main component of obtained essential oils was Carvacrol which represented $95.37 \%$ of oil content as oxygenated monoterpenes. The other important compounds of monoterpenes were determined as $\gamma$-Terpinene $1.39 \%$, p-Cymene $1.06 \%, \beta$-Pinene $0.49 \%, \alpha$-Pinene $0.35 \%, \alpha$ Phellandrene $0.15 \%$ and $\alpha$-Terpinolen $0.11 \%$. In addition, traces of Germacrene-d and transCaryophyllene as sesquiterpenes compounds. Badawy et al. (2020) reported that the major constituents of essential oil of wild $O$. syriacum ssp. sinaicum plants collected from different locations of Saint Kathrin Protectorate were carvacrol ranged from $74.2 \%$ to $92.68 \%$ from the total content of the essential oil. El-Alam et al. (2019) found that the soil type affected the Origanum syriacum L. chemotype. In addition, the essential oils compositions were affected by soil type as well as 
mycorrhizal inoculation. These conditions increased carvacrol and reduced thymol productions. It is obvious and supports these results concerning the high content of carvacrol in the essential oil of wild O. syriacum ssp. sinaicum plants.

The major components in the essential oil of $O$. syriacum ssp. sinaicum was dominated by thymol, $\gamma$-terpinene and p-cymene (Stefanaki et al., 2016). Also, the differences in essential oil quantity and similarity in almost of composition with differ in percentages were reported in previous studies (Rodríguez-Solana et al., 2014; Gendy et al., 2015; and Morshedloo et al., 2017). The studies show variation in essential oil constituents of $O$. syriacum growing in different areas of different countries. These variations in quantity, quality and constituent can be due to geographical location, soil composition, climate, seasonal variation, vegetative cycle stage, plant organ, age and harvesting stage (Zein et al., 2011).

Table 1: The chemical composition of essential oil of wild Origanum syriacum ssp. sinaicum grown in Saint Katherine protectorate.

\begin{tabular}{lccc}
\hline Compounds & Formula & RT $(\mathrm{min})$ & Area Sum \% \\
\hline $\boldsymbol{\alpha}-$ Phellandrene & $\mathrm{C}_{10} \mathrm{H}_{16}$ & 8.437 & 0.15 \\
\hline $\boldsymbol{\alpha}-$ Pinene & $\mathrm{C}_{10} \mathrm{H}_{16}$ & 8.718 & 0.35 \\
\hline $\boldsymbol{\beta}$-Myrcene & $\mathrm{C}_{10} \mathrm{H}_{16}$ & 10.686 & 0.09 \\
\hline $\boldsymbol{\beta}-$ Pinene & $\mathrm{C}_{10} \mathrm{H}_{16}$ & 11.915 & 0.49 \\
\hline $\boldsymbol{\alpha}$ - Terpinolen & $\mathrm{C}_{10} \mathrm{H}_{16}$ & 11.464 & 0.11 \\
\hline $\mathbf{1 , 3 , 8 - p - M e n t h a t r i e n e}$ & $\mathrm{C}_{10} \mathrm{H}_{14}$ & 11.876 & 0.9 \\
\hline p-Cymene & $\mathrm{C}_{10} \mathrm{H}_{14}$ & 12.111 & 1.06 \\
\hline $\boldsymbol{\gamma}$-Terpinene & $\mathrm{C}_{10} \mathrm{H}_{16}$ & 13.387 & 1.39 \\
\hline Santolina triene & $\mathrm{C}_{10} \mathrm{H}_{16}$ & 15.968 & 0.01 \\
\hline 1,9-Decadiyne & $\mathrm{C}_{10} \mathrm{H}_{14}$ & 18.13 & 0.02 \\
\hline Carvacrol & $\mathrm{C}_{10} \mathrm{H}_{14} \mathrm{O}$ & 23.566 & $\mathbf{9 5 . 3 7}$ \\
\hline trans-Caryophyllene & $\mathrm{C}_{15} \mathrm{H}_{24}$ & 25.872 & 0.05 \\
\hline Germacrene-d & $\mathrm{C}_{15} \mathrm{H}_{24}$ & 33.448 & 0.01 \\
\hline
\end{tabular}

$\mathbf{R T}=$ Retention time

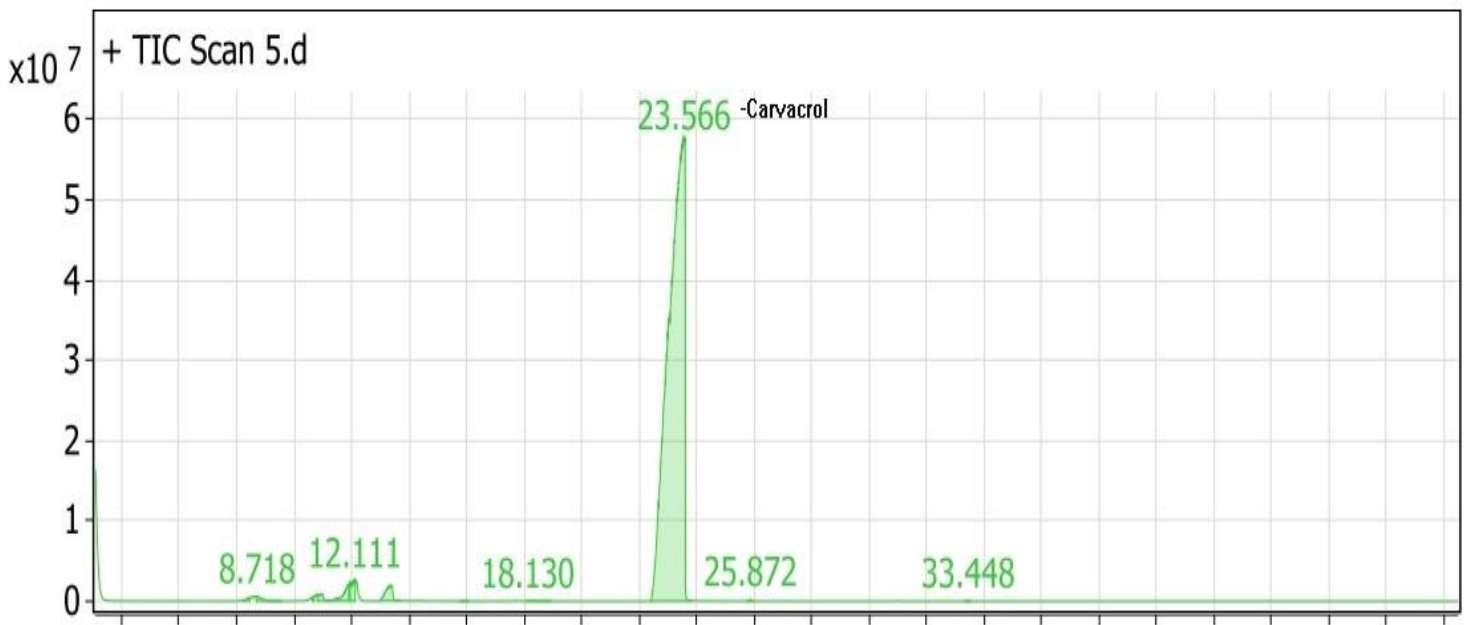

$\begin{array}{lllllllllllllllllllllll}4 & 6 & 8 & 10 & 12 & 14 & 16 & 18 & 20 & 22 & 24 & 26 & 28 & 30 & 32 & 34 & 36 & 38 & 40 & 42 & 44 & 46 & 48\end{array}$ Counts vs. Acquisition Time ( $\mathrm{min}$ )

Fig. 2: Peaks of essential oil components of $O$. syriacum ssp. sinaicum leaves.

\subsubsection{Antimicrobial Effect of Essential Oil of $O$. syriacum leaves:}

The essential oil of $O$. syriacum leaves demonstrated antimicrobial activity against Grampositive bacteria (Bacillus subtilis, Bacillus cereus, and Staphylococcus aureus) and Gram-negative 
bacteria (Escherichia coli). Also, O. syriacum essential oil was found to possess antifungal activity against Candida albicans.

The antimicrobial activities of the essential oil exhibited high activities against Bacillus subtilis with DIZ about $24 \mathrm{~mm}$, Bacillus cereus with DIZ about $22 \mathrm{~mm}$, Staphylococcus aureus with DIZ about $21 \mathrm{~mm}$ and Escherichia coli DIZ about $21 \mathrm{~mm}$. In addition, the essential oil exhibited high antifungal activity against Candida albicans with DIZ about $28 \mathrm{~mm}$.

The results were agreed with Shehadeh et al., (2019) who found that, the essential oils had the high percentage of carvacrol exhibited high activities against Gram-positive bacteria and Gram-negative bacteria. The monoterpenes specially carvacrol or/and thymol are responsible for the antibacterial. El Gendy et al. (2015) reported that, the essential oils of Origanum syriacum plant had been a strong source of antimicrobial compounds.

Many of the previous literature reported that various biological activities of carvacrol (Marinelli et al., 2018; Kirimer et al., 1995) also, carvacrol had showed bacteriostatic and bactericidal activity on food pathogens such as Vibrio cholerae, Campylobacter jejuni, E. Coli, Listeria monocytogenes, S. aureus, Staphylococcus epidermidis, Lactobacillus sakei, P. aeruginosa, Pseudomonas putida, Streptococcus mutans, and Bacillus subtilis (Hernández et al., 2017).

\section{Conclusion}

1. Wild $O$. syriacum ssp. sinaicum leaves had a high percentage of essential oil (6.5\%) as compared to other Origanum plants.

2. Essential oil of wild $O$. syriacum ssp. sinaicum leaves was reach in Carvacrol content (95.37\%).

3. Essential oil of wild $O$. syriacum ssp. sinaicum leaves had a great antimicrobial activates.

\section{References}

Alma, M.H., A. Mavi, A.Yildirim, M. Digrak and T. Hirata, 2003. Screening chemical composition and in vitro antioxidant and antimicrobial activities of the essential oils from Origanum syriacum L. growing in Turkey. Biochem. Pharmacol. Bull., 26:1725-1729.

Badawy, A.A., M.A. El-mohandes, A.M. Algharib, B.E. Hatab and E.A. Omer, 2020. The essential oil and its main constituents of Origanum syriacum ssp. sinaicum grown wild in Saint Katherine Protectorate, South Sinai, Egypt. Al-Azhar Journal of Agricultural Research. 45, (1), 116-131.

Baser, K.H., G. Buchbauer, 2009. Handbook of Essential Oils, Science, Technology, and Applications, CRC Press, New York.

Bisht, D.S., Rajendra C. Padalia, Lalit Singh, Veena Pande, Priyanka Lal and Chandra S. Mathela, 2010. Constituents and antimicrobial activity of the essential oils of six Himalayan Nepeta species. J. Serb. Chem. Soc. 75 (6) 739-747.

Boulos, L., 2002. Flora of Egypt. Volume 3: Verbenaceae-Compositae. Cairo, Egypt: Al-Hadara Publishing. p. 12.

Economou, G., G. Panagopoulos, P. Tarantilis, D. Kalivas, V. Kotoulas, I.S. Travlos, M. Polysiou, A. Karamanos, 2011. Variability in essential oil content and composition of Origanum hirtum L., Origanum onites L., Coridothymus capitatus (L.) and Satureja thymbra L. populations from the Greek island Ikaria. Ind. Crop. Prod., 33:236-241.

El-Alam, I., R. Zgheib, M. Iriti, M. El Beyrouthy, P. Hattouny, A. Verdin, J. Fontaine, R. Chahine, A.L.H. Anissa Lounès-Hadj Sahraoui and H. Makhlouf, 2019. Origanum syriacum Essential Oil Chemical Polymorphism According to Soil Type. Foods. 8, 90.

El Gendy, A.N., M. Leonardi, L. Mugnaini, F. Bertelloni, V.V. Ebani, S. Nardoni, F. Mancianti, S. Hendawy, E. Omer and L. Pistelli, 2015. Chemical composition and antimicrobial activity of essential oil of wild and cultivated Origanum syriacum plants grown in Sinai. Egypt. Ind. Crops Prod., 67, 201-207.

Hernández, H., A. Fraňková, T. Sýkora, P. Klouček, L. Kouřimská, I. Kučerová and J. Banout, 2017. The effect of oregano essential oil on microbial load and sensory attributes of dried meat. J. Sci. Food Agric., 97:82-87. 
Kirimer, N. and K.H.C. Ba,ser and G. Tümen, 1995. Carvacrol rich plants in Turkey. Chem. Nat. Compd., 31, 37-41.

Kordali, S., A. Cakir, H. Ozer, R. Cakmakci, M. Kesdek and E. Mete, 2008. Antifungal, phytotoxic and insecticidal properties of essential oil isolated from Turkish Origanum acutidens and its three components, carvacrol, thymol and p-cymene. Bioresource Technology, 99(18):87888795.

Marinelli, L. and A. Di Stefano and I. Cacciatore, 2018. Carvacrol and its derivatives as antibacterial agents. Phytochem. Rev. 17, 903-921.

Morshedloo, M.R., L.E. Craker, A. Salami, V. Nazeri, H. Sang and F. Maggi, 2017. Effect of prolonged water stress on essential oil content, compositions and gene expression patterns of mono- and sesquiterpene synthesis in two oregano (Origanum vulgare L.) subspecies. Plant Physiol. Biochem.; 111:119-128.

Moustafa, A.R.A., 2001. Impact of grazing intensity and human disturbance on the population dynamics of Alkanna orientalis growing in Saint Catherine mountains, South Sinai, Egypt. Pak. J. Biol. Sci., 4: 1020-1025.

Poulose A.J. and R. Croteau, 1978. Biosynthesis of aromatic monoterpenes: conversion of $\gamma$-terpinene to p-cymene and thymol in Thymus vulgaris L. Arch Biochem Biophys, 187:307-314.

Rodríguez-Solana, R., D.J. Daferera, C. Mitsi, P. Trigas, M. Polissiou and P.A. Tarantilis, 2014. Comparative chemotype determination of Lamiaceae plants by means of GC-MS, FT-IR, and dispersive-Raman spectroscopic techniques and GC-FID quantification. Ind. Crop. Prod., 62:22-33.

Sharifi-Rad, J., A. Sureda, G.C. Tenore and M. Daglia, 2017. Biological activities of essential oils: from plant chemoecology to traditional healing systems. Molecules, 22 (1), 1-55.

Shehadeh, M., N. Jaradat, M. Al-Masri, A.N. Zaid, F. Hussein, A. Khasati, G. Suaifan, R. Darwish, 2019. Rapid, cost-effective and organic solvent-free production of biologically active essential oil from Mediterranean wild Origanum syriacum. Saudi Pharmaceutical Journal, 27, 612-618.

Stefanaki, A., C.M. Cook, T. Lanaras, S. Kokkini, 2016. The oregano plants of chios island (Greece): Essential oils of Origanum onites L. growing wild in different habitats. Ind. Crop. Prod. 82:107-113.

Turner, G, J. Gershenzon, E.E. Nielson, J.E. Froehlich and R. Croteau, 1999. Limonene synthase, the enzyme responsible for monoterpene biosynthesis in peppermint, is localized to leucoplasts of oil gland secretory cells. Plant Physiology, 120: 879-886.

Valgas, C., S.M. DeSouza and E.F.A. Smânia, 2007. Screening methods to determine antibacterial activity of natural products, Braz.J. Microbiol.38, 369-380.

Zein, S., S. Awada, S. Rachidi, A. Hajj, E. Krivoruschko, H. Kanaan, 2011. Chemical analysis of essential oil from Lebanese wild and cultivated Origanum syriacum L. (Lamiaceae) before and after flowering. J Med Plants Res., 5:379-387. 